\title{
WIZERUNEK HUMANISTY W WERBALIZACJACH STUDENTÓW WYDZIALU HUMANISTYCZNEGO UMCS W LUBLINIE
}

\begin{abstract}
The intention of the authors is to attempt a recreation of the self-stereotype of a humanities person, by analyzing answers to the following questions/issues: 1) Who is a humanities person? 2) Name occupations in which such a person may be professionally involved. 3) List competences that are typical of a humanities person. 4) What distinguishes a person with a background in humanities from persons educated in different area? 5) Are such persons needed today?
\end{abstract}

\section{Key words}

Self-stereotype, stereotype, humanities background, student 


\section{O „KRYZYSIE HUMANISTYKI”}

W ostatnich latach wiele uwagi poświęca się znaczeniu nauk humanistycznych w różnych aspektach, zarówno tych pozytywnych, jak i negatywnych. Istotne miejsce zajmuje przy tym kwestia spadku zainteresowania tego rodzaju kształceniem samych kandydatów rozpoczynających swą uniwersytecką edukację i wybierających kierunki bardziej praktyczne. $\mathrm{Z}$ dużą dozą prawdopodobieństwa można stwierdzić, że znaczącą rolę w kreowaniu takich młodzieżowych wyborów miało i ma nadal funkcjonowanie w szerokim dyskursie publicznym terminu „kryzys humanistyki”, który przekłada się nie tylko na życie środowiska naukowego, ale również świata studenckiego. W ogromnym stopniu przyczynił się on de facto do aktualnej recepcji nauk humanistycznych w społeczeństwie. Jak to się stało, że zostały one dotknięte przez wspomniany „kryzys” - celowo zapisywany przez nas w cudzysłowie - nad którym wielu deliberuje, zaczynając od politycznych decydentów, a kończąc na samych żakach? Czy rzeczywiście humanistyka znalazła się w odwrocie, czy też może ten problem został sztucznie wywołany? Prof. Marcin Król, wypowiadając się na ten temat, stwierdza:

\footnotetext{
Humanistyka stoi w Polsce, wbrew banalnej krytyce niedoinformowanych specjalistów nauk ścisłych, całkiem dobrze. (...) To nie humanistyka, nie uczeni są mizerni, lecz cały świat wokół nich - od pieniędzy, przez przepisy, po taki brak zrozumienia, co to jest uniwersytet, że aż smutno. Odpowiem krótko, kto myśli, że uniwersytet to szkoła zawodowa, ten jest niepoprawnym osłem. A kto nie rozumie, że nauka myślenia jest największym darem, jaki możemy przekazać młodym ludziom, ten jest osłem w dwójnasób ${ }^{1}$.
}

W naszym odczuciu humanistyka płaci po trosze za konsekwencje zmian w szkolnictwie realizowanych na przełomie wieków. Taką konstatację wywodzimy między innymi z obserwacji procesu kształcenia na Wydziale Humanistycznym UMCS. System boloński, ze swym „3 + 2”, wprowadzając studia pierwszego i drugiego stopnia, a następnie nawet trzeciego, działając na rzecz rzekomej mobilności studentów, którzy mogliby rozpoczynać karierę zawodową już po trzech latach uniwersyteckiej edukacji, w rzeczywistości wprowadził więcej ograniczeń. Na przykład, kogo z przyszłego grona nauczycielskiego satysfakcjonowało prawo do nauczania tylko w szkole podstawowej, bo takież uprawnienia nabywano po trzyletniej edukacji? Odpowiedź jest jednoznaczna - niewielu. W konsekwencji zdecydowana większość i tak kontynuuje

\footnotetext{
${ }^{1}$ Król 2014.
} 
studia na drugim stopniu, ale jest zmuszona chociażby do napisania dwóch prac - licencjackiej i magisterskiej. Dotychczas wystarczyła tylko ta ostatnia.

$\mathrm{Z}$ pewnością system boloński umożliwił jednak dynamiczny rozwój kierunków humanistycznych zarówno w wyższych szkołach prywatnych, jak i w państwowych wyższych szkołach zawodowych rozrzuconych po całej Polsce. Nic dziwnego, że ten obszar nauki zaczął dominować nad kierunkami ścisłymi, których uruchamianie było zdecydowanie droższe. Nieliczni chyba zastanawiali się wówczas, jakie konsekwencje takiego podejścia odczuwane będą za kilka/kilkanaście lat, gdy rynek pracy będzie zapełniany wykształconymi - mniej lub bardziej - humanistami. Jak grzyby po deszczu powstawały też nowe uniwersytety proponujące rozbudowaną ofertę humanistyczną.

Niestety, nie było jednak wówczas zbyt wielu głosów kontestujących takie rozwiązanie. Dlaczego? Otóż zdecydowana większość, zarówno biorących w tym udział, jak i obserwatorów, podchodziła do tego, jeżeli nie z ogromnym aplauzem, to co najmniej z życzliwą neutralnością. Polityczni decydenci - bo wzrastał poziom wykształcenia społeczeństwa i odłożono w czasie napływ na rynki pracy rzesz młodzieży po likwidacji średniego szkolnictwa zawodowego, a poza tym często spłacano w ten sposób dług wdzięczności swoim lokalnym wyborcom; środowisko naukowe - bo uzyskało szansę na podreperowanie swoich budżetów, a przed niektórymi pojawiła się ponadto szansa na „zaistnienie w gronostajach”; wreszcie kandydaci na studentów ponieważ bardzo często była to jedyna szansa na zdobycie wyższego wykształcenia. $\mathrm{O}$ ile stworzony w ten sposób system edukacji bronił się, gdy po uzyskaniu tytułu licencjata na uniwersytety trafiali świetni, bardzo dobrzy czy przynajmniej dobrzy kandydaci na studia drugiego stopnia, o tyle sprawa przedstawiała się zgoła inaczej, gdy poziom młodych adeptów nauki zaczął się drastycznie obniżać. Ale czy mogło być inaczej, skoro ogarnął nas, przewidywany zresztą, niż demograficzny, a dotychczasowe zasady finansowania uczelni, uzależniające wysokość otrzymywanej dotacji od liczby studentów, zostały utrzymane? Wydaje się, że wystarczyło już wówczas wprowadzić algorytm uwzględniający „jakość”, a nie liczbę kandydatów, aby powstrzymać ten obłędny wręcz „pościg” za absolwentami szkół średnich.

Wygodniej, a może przede wszystkim taniej, było jednak „odkryć” i ogłosić światu, że w Polsce jest za dużo humanistów, a za mało przedstawicieli innych obszarów nauki. Dodano do tego, że nie są oni mobilni, są niewidoczni na arenie międzynarodowej i za mało piszą po angielsku, jakby zapomniano w ogóle o tym, jaką rolę spełniała, spełnia i powinna spełniać humanistyka w zachowaniu własnej tożsamości i dbałości o narodowe dziedzictwo. Jakby 
przestała nagle obowiązywać, aktualna przez wieki, maksyma zawarta w dziele Marka Tuliusza Cycerona pt. „O mówcy”: „Czyj wreszcie głos, jeśli nie mówcy, powierzy nieśmiertelności historię, świadka czasów, światło prawdy, życie pamięci, nauczycielkę życia, posłankę dawnych dziejów?”2. Uznano wręcz, że jej absolwenci niezbyt dobrze sobie radzą w dzisiejszych realiach. Ale czy rzeczywiście przeprowadzono stosowne w tym przypadku analizy? Przecież nawet wśród państwowych decydentów, ograniczając się jedynie do kilku ostatnich lat, sporo znajdziemy osób z humanistycznym wykształceniem, i to na czołowych stanowiskach, a wśród bezrobotnych dominują absolwenci kierunków obleganych, takich jak: prawo, administracja, zarządzanie, pedagogika, bezpieczeństwo narodowe i wewnętrzne. Ciekawe, że wszystkie one reprezentują stosunkowo młody obszar nauk społecznych, który wyodrębniono $\mathrm{z}$ nauk humanistycznych, co jest również bardzo symptomatyczne. Otóż uznano, że „humanistyczny” jest już passé, a „społeczny” będzie cool. Słusznie zatem zauważyli Krzysztof Mikulski i Jacek Wijaczka, że: „W minionych wiekach wrogami społecznymi były czarownice, żydzi, masoni i cykliści. Dzisiaj, mamy wrażenie, że w Polsce stali się nimi humaniści”’3.

Michał Bilewicz, Dominik Antonowicz i Emanuel Kulczycki w artykule „Wielki świat lub zaścianek”, diagnozując niską skuteczność polskich humanistów w staraniach o granty europejskie, oceniają, że są tego dwie przyczyny:

Pierwsza z nich to duża dostępność grantów dla humanistów i nauk społecznych w Polsce. (...) Istniejące już programy finansowania badań (FNP, NCN, NPRH) umożliwiają stosunkowo łatwe sfinansowanie w Polsce przedsięwzięcia z obszaru nauk humanistycznych i społecznych. Drugą przyczyną stosunkowo słabego zaangażowania (...) jest niewielka obecność naszych uczonych w międzynarodowym obiegu naukowym. Niewielu polskich humanistów publikuje artykuły w czołowych filozoficznych, socjologicznych, antropologicznych czy psychologicznych czasopismach naukowych. (...) Podobnie jest zresztą z monografiami: niewiele książek polskich humanistów ukazuje się $\mathrm{w}$ renomowanych wydawnictwach. W efekcie świat dowiaduje się o najnowszej historii Polski z prac Timothy'ego Snydera $(\ldots)^{4}$.

Prawdą jest, że Timothy Snyder, podobnie zresztą jak Norman Davis, znakomicie rozpowszechniają naszą historię, ale przecież materiały do swych prac w znacznej mierze czerpią z ustaleń polskich naukowców, którzy publikują znakomite prace w oficynach ogólnopolskich, a nie lokalnych, i mają od lat ugruntowaną renomę.

2 „Historia vero testis temporum, lux veritatis, vita memoriae, magistra vitae, nuntia vetustatis, qua voce alia nisi oratoris immortalitati commendatur?”. Zob. M.T. Cyceron 2010, s. 256, 259.

${ }^{3}$ Mikulski i Wijaczka 2014, s. 141.

${ }^{4}$ Bilewicz, Antonowicz i Kulczycki 2014.

${ }^{5}$ Mikulski i Wijaczka 2014, s. 147-148. 
Należy postawić pytanie, czy nie za bardzo fetyszyzujemy język angielski, listę filadelfijską, ERIH i tym podobne zestawienia. Owszem, wiele jest zagadnień z polskiego dziedzictwa, które mogą zainteresować mieszkańców innych państw, ale również wiele jest takich, które nie mają na to szans (np. zagadnienia językoznawcze $\mathrm{z}$ zakresu gwar ludowych). Nie oznacza to przecież, że prace te są mniej wartościowe. Tymczasem, wtłaczając humanistykę w zasady ocen przystających do nauk ścisłych, na starcie postawiono ją na przegranej/gorszej pozycji. Owszem, nasz dorobek musi być oceniany/ punktowany, ale róbmy to, uwzględniając różnice poszczególnych dyscyplin ${ }^{6}$. Może warto stworzyć listę czasopism sztandarowych dla polskiej humanistyki z uwzględnieniem ich rzeczywistej wartości? Wypada w tym miejscu przytoczyć słowa Karola Myśliwca, który w jednym z wywiadów stwierdził, że naśladujemy

jak papugi wszystko, co się dzieje na Zachodzie. Nawet to, z czego Zachód się wycofuje - choćby z takiej metrycznej oceny nauk humanistycznych. Na punkty przeliczana jest cała działalność naukowa. Przy czym za wielorozdziałową, prawdziwą monografię dostaje się tyle samo punktów co za sześcioarkuszowy artykuł do zagranicznego pisma. Nikt się nie zastanawia, że nie ma obiektywnych kryteriów do oceny tego, kto tworzy dzieło wybitne. (...) Ameryka i Anglia głośno krzyczą i wycofują się z tego systemu, a my, jak te opóźnione krowy, zaczynamy to wprowadzać. To prowadzi wprost do likwidacji humanistyki'

A służy temu wyścig, w którym uczestniczymy - szybciej, więcej, w czasopiśmie za jak największą liczbę punktów.

W 2013 r. ks. prof. Antoni Dębiński, podzielając niepokój środowisk uniwersyteckich dotyczący ministerialnej polityki wobec humanistyki, zaznaczył że:

Nauki humanistyczne są podstawowym elementem nie tylko kultury uniwersyteckiej, ale przede wszystkim tradycji. Odejście od wartości, których nośnikiem są nauki humanistyczne, może mieć zgubne skutki dla naszej kultury, a nawet cywilizacji. To, jak uprawiamy humanistykę dziś, w aktualnie istniejącym otoczeniu społeczno-ekonomicznym, będzie miało długofalowe skutki

i dalej:

Polityka ministerstwa oraz pragmatyczne podejście do nauki obecne w działaniach oświatowych prowadzi do systematycznego rugowania z programów szkolnych przedmiotów humanistycznych ${ }^{8}$.

\footnotetext{
${ }^{6}$ Uczestnicząc przez ostatnie cztery lata w pracach różnych komisji uniwersyteckich, mogliśmy bardzo dobrze zaobserwować zjawisko odnoszenia się przedstawicieli nauk ścisłych do dorobku humanistów w zakresie zdobywanych punktów, indeksu cytowań czy wskaźnika Hirscha.

${ }^{7}$ Myśliwiec 2014.

${ }^{8}$ Dębiński 2013.
} 
Idąc tym tropem, Andrzej Kokowski i Robert Litwiński zadali pytanie: „Czy Humanistyka umiera?”. Postawiono je po seminarium zatytułowanym: „Nauki Humanistyczne i Społeczne w Polsce 2014: Analiza - Diagnoza - Prognoza", jakie zorganizowała Konferencja Rektorów Uniwersytetów Polskich w kwietniu 2014 r. O ile jednak spotkanie zostało poważnie potraktowane przez przedstawicieli uniwersytetów, o tyle zgoła inaczej potraktowali je reprezentanci resortu. Pani minister Lena Kolarska-Bobińska nie pojawiła się, a desygnowany na jej miejsce sekretarz stanu Marek Ratajczak wysłuchał zaledwie referatów wstępnych. Pomimo tego, że padło wówczas wiele ważnych słów, wysłuchali ich wyłącznie przedstawiciele środowiska identyfikującego się z prelegentami, bo decydentów nie było! ${ }^{9}$

Zastanawiano się, co zagraża humanistyce - tej pojmowanej jako nauka i jako zestaw kierunków studiów. Odpowiedź była prosta - przede wszystkim konkurencja wewnątrz uczelni, kiedy to tradycyjna humanistyka dzielona jest, wręcz „rozrywana” na strzępy, poprzez tworzenie nowych, często efemerycznych kierunków z marketingowo chwytliwymi nazwami. Remedium na to mogłaby się okazać się poprawa warunków studiowania, a przede wszystkim stworzenie trwałej ścieżki dla udziału studentów w realizacji naukowych projektów grantowych. Dobrym rozwiązaniem byłby również powrót do systemu studiów pięcioletnich, połączony z ogólnodostępnymi specjalistycznymi kursami, które zwiększyłyby szanse młodych ludzi na rynku pracy. Wszak wykształcenie humanistyczne to wykształcenie wszechstronne ${ }^{10}$.

A jak w tym wszystkim odnajdują się studenci - spadkobiercy akademików, beanów i żaków? Jak postrzegają humanistykę i samych humanistów?

\section{PRZYSZLI HUMANIŚCI O HUMANISTACH}

Opinie, że studiowanie, a szczególnie studia humanistyczne, są passé, co próbowaliśmy wykazać na wstępie, wydają się coraz powszechniejsze. Czy rzeczywiście jednak jest tak, że młodzi ludzie nie chcą pogłębiać wiedzy z tej dziedziny? Co sądzą na ten temat ci, którzy właśnie wybrali studia humanistyczne? Kim - według nich - jest humanista? Jakie zawody może on wykonywać? Jakie kompetencje są właściwe humaniście? Co odróżnia osobę legitymującą się wykształceniem humanistycznym od nie-humanis-

\footnotetext{
${ }^{9}$ Kokowski i Litwiński 2014, s. 41.

${ }^{10}$ Ibidem, s. 42; Mikulski i Wijaczka 2014, s. 148.
} 
tów? Czy potrzebni są dzisiaj humaniści? Takie pytania skierowaliśmy łącznie do 250 studentów Wydziału Humanistycznego Uniwersytetu Marii Curie-Skłodowskiej w Lublinie, co uważa się za dużą grupę badawczą.

Wbrew dość rozpowszechnionym przekonaniom - dowodzi Tadeusz Pilch - wielkość populacji nie wywiera zasadniczego wpływu na konieczną wielkość próby. Nie jest to prawdą, że jeśli populacja licząca 10 tysięcy jednostek reprezentowana jest przez próbę liczącą 100 jednostek, to populację złożoną z 20 tysięcy jednostek powinna reprezentować próba 200-elementowa.

i dodaje:

(...) próba licząca poniżej 30 jednostek - to mała próba. Próba o liczbie jednostek nie mniejszej niż 100 - to duża próba. Próba, której liczba jednostek zawiera się w granicach 30 do 100, to próba „przejściowa”"11.

W tekście posłużyliśmy się metodą sondażu diagnostycznego wspartą metodą ankietową. Dodać wypada, że ankieta miała charakter otwarty, gdyż tego typu pytania testowe „stwarzają ramy dla indywidualnych, bardziej osobistych wypowiedzi"12. Podstawą analiz, interpretacji i wnioskowania stały się zatem autentyczne werbalizacje tworzone przez młodzież.

Naszym zamierzeniem była próba odtworzenia autostereotypu humanisty, który - jak każdy stereotyp - opiera się na schematycznych wyobrażeniach, odwołuje się do podstawowych modeli myślenia o świecie, a te przecież niezwykle łatwo ulegają uproszczeniom, schematyzacji i często nieadekwatności. Stereotypowe, czyli potoczne widzenie świata jest jednak typowe dla przeciętnego użytkownika języka, pomaga mu bowiem porządkować otaczającą go rzeczywistość, symplifikując napływające informacje ${ }^{13}$. Stereotyp jest swoistym filtrem, przez który przepuszczamy nabyte później doświadczenia ${ }^{14}$. Zawęża nasze spojrzenie na rzeczywistość, przekazuje nam, które dane docierające $z$ otoczenia powinniśmy akceptować, a które odrzucić jako nieprzystające do posiadanego przez nas szablonu ${ }^{15}$. Stereotyp jako jeden z rodzajów porządkowania świata wydaje się jednak wręcz niezastąpiony w procesie poznawania rzeczywistości, człowieka cechuje bowiem potrzeba posiadania „jasnej, subiektywnie prawdziwej i jednoznacznej wizji świata oraz awersja

${ }^{11}$ Pilch 1998, s. 117-118.

${ }^{12}$ Zaczyński 1995, s. 150-151.

${ }^{13} \mathrm{Na}$ temat stereotypów jako zbioru tendencyjnych sądów, zawierających w sobie cechy o dużym stopniu stabilizacji, silnie utrwalonych w języku i kulturze, piszą m.in.: Bartmiński 2007; Bartmiński i Panasiuk 2001; Kofta, Jasińska-Kania (red.) 2001; Telus 1998, s. 136.

${ }^{14}$ Por. Pszoniak 2015.

${ }^{15}$ Por. Nelson 2003, s. 25. 
wobec niejednoznaczności i niepewności" ${ }^{16}$. Stereotypy - zdaniem Józefa Chałasińskiego - odgrywają „niepoślednią rolę"17 w stosunkach społecznych, pozwalają bowiem identyfikować się z własną grupą społeczną ${ }^{18}$. To właśnie te cząstkowe „obrazy w głowie ludzkiej” 19 sprawiają, że wyobrażenie rzeczywistości jest jednocześnie upraszczane, ale i wyraźnie ukierunkowane albo pozytywnie, gdy dotyczy ono nas (autostereotyp, stereotyp pozytywny), albo negatywnie, gdy odnosi się do innych (heterostereotyp, stereotyp negatywny $)^{20}$.

Prosty sąd stereotypowy ${ }^{21}$, że „Humanista jest oczytany”, można uznać za zdanie analityczne, ponieważ rzekomo komunikuje jakąś cechę, ale cecha ta jest przecież równocześnie $\mathrm{z}$ góry założona. $\mathrm{Z}$ kolei $\mathrm{w}$ wypowiedzi typu: "Jest humanistą, ale zna się na naukach ścisłych i technicznych" stereotyp nie został wypowiedziany wprost, ale zawarty jest implicite i można go wyinterpretować w postaci sądu przekonaniowego: „Humaniści zwykle nie znają się na naukach ścisłych i technicznych”. „Cechą stereotypów jako podklasy pojęć jest - zdaniem Jerzego Bartmińskiego - to, że łączą charakterystyki opisowe przedmiotu (przysłowiowe „ziarno prawdy”) z ocenami emocjonalnymi i wartościowaniem. Stereotypowy obraz świata - niezależnie od tego, w jakim stopniu jest akceptowany przez zbiorowość i językowo utrwalony - jest obrazem subiektywnym, podmiotowym"22.

Spróbujmy zatem popatrzeć, jak postrzegają samych siebie humaniści. Czy swymi wypowiedziami potwierdzą funkcjonujące przekonanie o zbędności osób $\mathrm{z}$ wykształceniem humanistycznym w życiu społecznym, o czym Agnieszka Krzemińska w artykule zatytułowanym „Erudyta zawsze modny” tak pisze: „Zewsząd słychać utyskiwanie, że poziom studiów w Polsce spada, a dyplom przestaje się liczyć. Najwięcej cięgów zbiera humanistyka, której jest ponoć zbyt dużo, jest mało przydatna i na niskim poziomie"23.

Odwołamy się najpierw do wiedzy systemowej. „Słownik języka polskiego" pod redakcją Mieczysława Szymczaka podaje definicję rzeczownika „humanista”, uwzględniając płeć osoby trudniącej się tą profesją. I tak „humanista” to:

\footnotetext{
${ }^{16}$ Błoch i Doliński 2004, s. 205-206.

${ }^{17}$ Chałasiński 1935, przywołujemy za: Bartmiński 2007, s. 56.

${ }^{18}$ Nowak 2002, s. 65-66.

${ }^{19}$ Lippmann 1922.

${ }^{20}$ Bokszański 1997, s. 28.

${ }^{21}$ Więcej na ten temat patrz: Bartmiński 2007.

${ }^{22}$ Ibidem, s. 105.

${ }^{23}$ Krzemińska 2015, s. 62.
} 
1) przedstawiciel humanizmu, uczony okresu Odrodzenia;

2) specjalista w zakresie nauk humanistycznych; człowiek mający wykształcenie humanistyczne,

ale „humanistka” to już wyłącznie „specjalistka w zakresie nauk humanistycznych; kobieta mająca wykształcenie humanistyczne"24.

Znacznie nowsza praca - „Inny słownik języka polskiego” - uwzględnia trzy znaczenia słowa, rezerwując je dla obu płci:

1) ktoś, kto ma wiedzę i wykształcenie w zakresie nauk humanistycznych,

2) ktoś, kto kieruje się w życiu zasadami humanizmu,

3) przedstawiciel humanizmu epoki Odrodzenia ${ }^{25}$.

Konstruowane przez studentów objaśnienia nie zawsze odbiegają od definicji zamkniętych, strukturalnych, najczęściej jednak są to opisy otwarte, określane mianem definicji kognitywnych ${ }^{26}$. Tak więc wśród proponowanych przez respondentów charakterystyk wydzielić można:

- definicje klasyczne, które są niemal identyczne ze słownikowymi, np.: „Humanista to człowiek wykształcony, oczytany, obyty w świecie. Mający wykształcenie humanistyczne. Specjalista w zakresie nauk humanistycznych. Osoba kierująca się zasadami humanizmu. Bada siebie samego, próbuje opisać kondycję człowieka”; „osoba specjalizująca się w dziedzinie nauk humanistycznych. Zwolennik, przedstawiciel humanizmu; przedstawiciel humanizmu, specjalista $\mathrm{w}$ dziedzinie nauk humanistycznych i jednocześnie ktoś, kto kieruje się w życiu zasadami szeroko pojętego humanizmu";

- definicje ostensywne, w których młodzi ludzie wyjaśniają słowo przede wszystkim poprzez wskazywanie nazwisk osób, np.: „Humanista to człowiek wykształcony wszechstronnie: oczytamy, światły. Takimi humanistami byli: Dante Alighieri czy Mikołaj Kopernik”; ,humanista to ktoś tak wszechstronny jak Leonardo da Vinci”; ,to ludzie tacy jak Cyceron”;

- definicje cząstkowe, które realizowane są:

\footnotetext{
${ }^{24}$ Szymczak (red.) 1982, 1, s. 757. W odniesieniu do kobiety autorzy hasła zarezerwowali wyłącznie drugie znaczenie słowa, odmawiając jej możliwości bycia przedstawicielką humanizmu. W tym artykule, niestety, nie zajmujemy się sprawami lingwistyki płci, toteż odsyłamy zainteresowanych do książki Małgorzaty Karwatowskiej i Jolanty Szpyry-Kozłowskiej 2010, w której autorki omawiają wybrane aspekty seksizmu we współczesnej polszczyźnie. W przypadku tego hasła jest on widoczny niezwykle wyraziście.

${ }^{25}$ Bańko (red.) 2000, 1, s. 517.

${ }^{26}$ „Definicja kognitywna za cel główny przyjmuje zdanie sprawy ze sposobu pojmowania przedmiotu przez mówiących danym językiem, tj. ze sposobu utrwalonej społecznie i dającej się poznać poprzez język wiedzy o świecie, kategoryzacji jego zjawisk, ich charakterystyki i wartościowania”. Bartmiński 1988, s. 169-170. Na temat rodzajów definicji patrz np.: Krzyżanowski 1993.
} 
$\checkmark$ poprzez wyliczanie cech typowych, charakterystycznych - zdaniem respondentów - dla humanisty, np.: „Humanista to człowiek wyzwolony $\mathrm{z}$ autorytetu kościelnego, odważny $\mathrm{w}$ poszukiwaniu prawdy"; „wszechstronnie wykształcony, znający języki obce, historię i gramatykę”; „to człowiek społecznie zaangażowany, oddany ojczyźnie (patriota). Nabywa wiedzę z wielu dziedzin, włada językami obcymi, rozumie inne kultury, lepiej się komunikuje i nawiązuje kontakty”; „to człowiek lubujący się w książkach, człowiek, który pamięta o tradycji i godności człowieka”; „człowiek, który myśli racjonalnie, który rozstrzyga dylematy etyczne, moralne, kulturowe, ma antropocentryczną postawę intelektualną i moralną”; „to osoba, która potrafi myśleć kreatywnie, a nie wyłącznie utartymi schematami”; „otwarty na pomysły, ma dużą wyobraźnię, sam jest pomysłowy”; „człowiek o bardzo elastycznym umyśle, ciągle myślący i analizujący";

$\checkmark$ w oparciu o antynomiczność, wykluczanie, np.: „Humanista to człowiek, który nie interesuje się naukami ścisłymi”; „osoba, która nie rozumie przedmiotów ścisłych”; „człowiek, który nie ma zdolności w zakresie nauk ścisłych”; „człowiek, który jest kiepski z przedmiotów ścisłych”; „osoba nieprzepadająca za naukami ścisłymi”; „ktoś, kto nie lubi bądź nie przepada za naukami ścisłymi i lepiej odnajduje się w filozofii”; „osoba bez umiejętności matematycznych”; „brakuje jej dyspozycji do nauk ścisłych, przyrodniczych”; „człowiek kiepski z przedmiotów ścisłych";

$\checkmark$ poprzez wskazywanie dziedzin wiedzy typowych dla humanisty, np.: „Humanista to osoba zajmująca się naukami humanistycznymi takimi, jak: historia, wiedza o społeczeństwie, język polski, psychologia; człowiek, który interesuje się literaturą, kulturą, sztuką, filozofią; to fachowiec w dziedzinach takich jak: filmy, muzyka, sztuka, architektura, rzeźba, języki; znawca nauk humanistycznych szeroko pojętych, w tym historii kultury, języka, sztuki, literatury itd.”.

Analiza konstruowanych przez studentów objaśnień rzeczownika „humanista" prowadzi do kilku - jak sądzimy - istotnych spostrzeżeń:

1. Respondenci prezentują raczej humanizm świecki, stąd w ich wypowiedziach wskazywanie na konieczność odizolowania się od doktryny Kościoła, np.: „Humanista to człowiek wyzwolony z autorytetu kościelnego”; „to człowiek myślący samodzielnie, a nie ktoś podporządkowany nakazom 
kościelnym”; „człowiek, który potrafi z odwagą iść własną drogą i nie chce ulegać zarówno instytucjom świeckim, jak i kościelnym".

2. Wymieniając walory humanisty studenci, prezentują zarówno jego cechy charakteru/osobowości (np.: „tolerancyjny”, „śmiały”, „kreatywny”, „lojalny”, „operatywny”, „wrażliwy”), jak i intelektu (np.: „inteligentny”, „mądry”, „wykształcony”, „błyskotliwy”, „oczytany”, „erudyta”). Wszystkie te epitety mają podkreślić rangę humanisty, czemu służą również dodawane do nich przysłówki: „bardzo”, „niezwykle”, „wybitnie”.

3. W tworzonych definicjach ankietowani odwołują się wręcz do humanizmu renesansowego, stąd m.in. przywołanie maksymy Terencjusza „Homo sum et nihil humanum a me alienum esse putto" i stawianie w centrum człowieka i tego, co z nim związane. Taka afirmacja osoby ludzkiej pojawia się w wypowiedziach typu: „Humanista to człowiek na pierwszym miejscu stawiający drugiego człowieka i człowieczeństwo w ogóle”; „w centrum jego zainteresowań znajduje się jednak człowiek; zainteresowany ludzką naturą"; „zainteresowany troską o potrzeby, szczęście, godność i swobodny rozwój człowieka”; „przede wszystkim zajmujący się człowiekiem, jego miejscem na ziemi”.

4. Dokonując charakterystyki humanisty, studenci nierzadko sami sobie przeczą. $Z$ jednej strony bowiem prezentują go jako osobę wszechstronną, która „nie zamyka się na żadną dziedzinę nauk”, z drugiej zaś podkreślają brak biegłości w zakresie nauk ścisłych, stosując epitety negatywnie wartościujące: „kiepski”, „marny”, „nędzny”, „słaby” („z nauk / przedmiotów ścisłych / matematycznych / przyrodniczych").

5. Wypowiedzi wyekscerpowane $\mathrm{z}$ ankiet są wyraźnie naładowane emocjami, np.: „człowiek, który potrafi zachwycać się słowami; lubujący się w książkach”; „rozmiłowany w czytaniu”; „cechuje go olbrzymi wprost pęd do wiedzy".

Kolejna dyspozycja skierowana do respondentów dotyczyła wymienienia zawodów, które może wykonywać humanista. Okazało się, że ich lista jest niezwykle obszerna, obejmuje bowiem ponad sto profesji. Studenci deklarują, że humanista może wykonywać każdy zawód, np.: „Humaniści mogą wykonywać niemal każdy zawód”; „wszystkie - ta wiedza nie koliduje z żadną specjalizacją, wręcz ją wzbogaca”; „wszystkie, bo nic co ludzkie nie jest im obce” albo używają określeń nieprecyzyjnych, zbyt ogólnikowych, pisząc: „zawody związane z branżą turystyczną”; „zawody związane z życiem kulturalnym”; „każdy, ale przede wszystkim te związane z edukacją, reklamą, marketingiem, 
zarządzaniem ludźmi”; „działacz fundacji, placówek rządowych oraz organizacji pozarządowych".

Poza wypowiedziami, które określilibyśmy jako nadmiernie optymistyczne, bo predestynujące humanistę do wykonywania każdej profesji, znalazły się konkretne wskazania. Można wśród nich wydzielić zawody: a) wymagające długotrwałego przygotowania, na ogół konieczności odbycia studiów wyższych, np.: „animator kultury”, „antropolog”, „archeolog”, „architekt”, „archiwista”, „filmoznawca”, „filozof”, „historyk literatury/sztuki”, „krytyk filmowy/literacki/teatralny”, „ksiądz”, „kustosz”, „logopeda”, „nauczyciel”, „pedagog”, „psychiatra”, „psycholog”, „psychoterapeuta”, „socjolog”, „teatrolog”, „wykładowca”; b) wymagające odpowiednich kwalifikacji (wiedzy, umiejętności), niekoniecznie związanych $\mathrm{z}$ edukacją instytucjonalną ${ }^{27}$, np.: „biznesmen”, „dyrektor artystyczny”, „edytor”, „korektor”, „mediator”, „pisarz”, „prezenter”, „publicysta”, „rzecznik prasowy”, „reporter”, „sędzia”, „tłumacz”, „trener personalny”; c) tzw. zawody twórcze, np.: „aktor”, „bloger”, „fotograf”, „operator kamery”, „projektant mody”, „redaktor”, „reżyser”, "scenarzysta”; d) związane z edukacją (nauczaniem i wychowaniem) - tu przede wszystkim można umieścić „nauczyciela”. Studenci nie tylko wymieniają nauczycieli konkretnych przedmiotów szkolnych, np.: „języka polskiego”, „historii”, „języków obcych”, „filozofii”, „WOS-u”, „,historii sztuki”, ale również poziomów edukacji, stąd "nauczyciel akademicki” i "nauczyciel w szkole podstawowej”; e) związane z usługami, np.: „kasjer”, „kucharz”, „pracownik fizyczny”, „urzędnik”, „sprzedawca”.

Respondenci, wyliczając profesje, w których może odnaleźć się humanista, wymieniali także nazwy wyższych urzędników, przedstawicieli władz publicznych, np.: „dyrektor”, „kierownik”, „minister”. Pojawiły się również jednostkowe wskazania, które trudno określić mianem zawodu, takie jak: „ministrant”- „osoba posługująca w liturgii, najczęściej w czasie sprawowania Eucharystii” czy „podróżnik”.

Studenci zostali również poproszeni o wymienienie kompetencji właściwych humaniście. Okazuje się, że młodzi ludzie - słusznie - wskazywali trzy atrybuty wyróżniające osobę, która sprawnie, skutecznie i na wysokim poziomie realizuje określone zadania. Należały do nich:

${ }^{27}$ Mamy świadomość, że zaproponowana przez nas klasyfikacja nie jest rozłączna, bowiem zawody wymagające odpowiednich kwalifikacji na ogół wiążą się z koniecznością odbycia studiów wyższych. Chodziło nam raczej o podkreślenie faktu, że nie zawsze ukończenie uczelni wyższej staje się równoznaczne z możliwością podjęcia określonego zajęcia, np. sędzia poza ukończeniem studiów musi wykazać się odpowiednimi kompetencjami, np. osobowościowymi. 
- wiedza, w której zakres włączają badani informacje nabyte w toku kształcenia oraz sprawność i poprawność ich spożytkowania, np.: „elokwencja”, „,inteligencja”, „duże/rozległe oczytanie”, „mądrość”, „otwarty na wiedzę”, "posługiwanie się językami obcymi”, „znajomość języków obcych/starożytnych”, „rozległa/wszechstronna/świetna wiedza z zakresu literatury (polskiej/światowej)/języka/historii/mediów, socjologii, antropologii kultury, historii sztuki, komunikacji”, „rozumienie mechanizmów funkcjonujących w świecie”, „szerokie/wszechstronne wykształcenie”, „znajomość gramatyki i ortografii”, „,znajomość szeroko pojętej kultury i sztuki”, „,znajomość natury człowieka";

- umiejętności, dzięki którym lepiej możemy sobie radzić w życiu; praktyczna znajomość czegoś i zarazem biegłość w czymś, np.: „asertywność”, „czytanie ze zrozumieniem”, „dobra/efektywna/sprawna komunikacja”, „elastyczność/łatwość/sprawność/szybkość nawiązywania kontaktów”, „empatia”, „komunikacja interpersonalna/niewerbalna/werbalna”, „kreatywność”, „krytyczne myślenie”, „posiadanie pasji, umiejętność analizowania faktów/dzieł kultury/sztuki/argumentowania/kontrolowania emocji/pracy z książką/pisania/poprawnego mówienia/prowadzenia negocjacji/radzenia sobie ze stresem i trudnymi sytuacjami/rozumienia siebie i innych/rozwiązywania problemów/wyrażania własnych opinii/współpracy w zespole”, „samodyscyplina”, „wysoka kultura osobista”;

- postawy, czyli reakcje, zachowania człowieka wobec świata społecznego. Respondenci jednoznacznie opowiadają się za postawą nonkonformizmu. Cenią w humaniście to, że nie ulega on wpływom, nie poddaje się społecznej presji, ale żyje $\mathrm{w}$ zgodzie $\mathrm{z}$ własnymi przekonaniami, prezentując własne wartości, poglądy, zasady czy normy, np.: „ciekawość świata”, „odwaga w wygłaszaniu własnych poglądów/obrony własnych opinii”, „otwarty umysł”, „otwartość na innych/na nową wiedzę/na świat”, „poczucie własnej wartości”, „szerokie horyzonty”, „skromność, „tolerancja”, „trwanie przy własnych poglądach”, „przy własnym świecie wartości”.

Kolejna dyspozycja dotyczyła odpowiedzi na następujące pytanie: „Co odróżnia osobę legitymującą się wykształceniem humanistycznym od nie-humanistów?".

Studiujący kierunki humanistyczne dostrzegają liczne różnice wynikające $\mathrm{z}$ wyboru wykształcenia. Zdaniem młodych adeptów nauki humanistę od niehumanisty odróżniają przede wszystkim następujące walory:

- wszechstronność, np.: „Humanista ma wszechstronne zainteresowania”; „posiada szerokie horyzonty myślowe, wszechstronnie uzdolniony”; 
„wszechstronnie wykształcony”; ,jest wszechstronny, większy akcent stawia na człowieka niż technologie, abstrakcyjny świat (np. teorii ekonomicznych)";

- dociekliwość, np.: „Humanista zawsze chce pogłębiać swoją wiedzę. Nigdy nie nasyci się wiedzą. Ciągle chce rozumieć więcej”; „dociekanie prawdy we własnym zakresie, bez szukania jej w mitologii i wierzeniach, optymistyczne nastawienie do ludzkich możliwości”;

- wrażliwość, która może być kojarzona ze słabością, bowiem kogoś nadmiernie wrażliwego niezwykle łatwo zranić, dotknąć. Wydaje się jednak, że studenci wrażliwość humanisty rozumieją jako nieobojętność, czułość, otwartość na drugiego człowieka/innych ludzi, np.: „Humanista to człowiek rozumiejący drugiego człowieka, a więc ktoś wrażliwy”; „przejawiający większą wrażliwość na świat”; „wrażliwy nie tylko na innych, ale na sztukę, kulturę"; "człowiek wrażliwy, dobry, otwarty na życie, emocje i innych ludzi”; „potrafi zrozumieć innych, chce zagłębiać wiedzę dotyczącą ludzi i ludzkości. Jest żywo zainteresowany sprawami społeczeństwa";

- kreatywność, np.: „Humanista nie stawia tylko na logikę, ale szuka rozwiązań kreatywnie. Nie trzyma się twardo utartych schematów, dla niego istnieją też inne kolory niż czarne, które jest czarne i białe, które jest białe"; „mają inne podejście do problemów świata, są bardziej kreatywni”; „najczęściej są to osoby kreatywne, często to artyści, wyczuleni esteci”; „to osoby pomysłowe, szukające oryginalnych rozwiązań”; „cechuje go [humanistę] twórcze myślenie";

- elastyczność i efektywność, która przejawia się w tym, że humaniści realizują się z sukcesami w różnych dziedzinach, np.: „Humanista jest człowiekiem o otwartym umyśle, który pozwala mu na ciągłe przyswajanie zmieniających się elementów kulturowych. Ma wyrobioną opinię na każdy temat i umie się wypowiedzieć w każdej kwestii, co pozwala mu na podejmowanie różnych zawodów"; "jest otwarty na nowe wyzwania, może się łatwo przekwalifikować w odróżnieniu do przedstawicieli zawodów technicznych"; „Humaniści wydają mi się bardziej elastyczni, bo potrafią przystosować się do warunków, które zastają i do obowiązków, które muszą wypełnić";

- umiejętność pracy $\mathrm{w}$ zespole przejawiająca się takimi kompetencjami, jak: umiejętność komunikowania się z innymi, słuchania ich, rozumienia ich stanowisk oraz zdolność do obiektywnej oceny ich pracy, np.: „Humaniści są lepszymi współpracownikami i liderami”; „lepiej współpracują w grupie, dostosowują się i wprowadzają w jej życie swoją pozytywną aktywność"; „potrafią pracować w grupie, co odróżnia ich od np. matematyków, którzy 
wolą «liczyć» samemu. Humanista jest otwarty na innych, potrafi ich zrozumieć, docenić”; „charakteryzuje go umiejętność budowania relacji, praca z ludźmi, kontrolowanie stresu”; ,empatyczne podejście do współpracowników".

Wszystkie wskazane walory składają się na wizerunek humanisty jako człowieka przyzwoitego, którego cechuje postawa zgodna z zasadami etycznymi i moralnymi, czego najlepszym potwierdzeniem następujące wypowiedzi: „Humaniści to ludzie zdolni do myślenia filozoficznego, interesują ich problemy natury etycznej, moralnej, często cechuje ich wiara w Boga”; „to kreatorzy właściwych postaw”; „Humanista kieruje się w swojej pracy zasadami etyki i moralności, głosi te idee. Etyka i moralność determinują działalność humanisty".

Obok wskazywanych pozytywów badani dostrzegają również negatywy, które $\mathrm{w}$ istotny sposób dopełniają wizerunek humanisty. Należą do nich względy finansowe i problemy związane $\mathrm{z}$ zatrudnieniem, które - ich zdaniem - są ważnym czynnikiem różnicującym, stąd wypowiedzi typu: „brak pracy”; „niższe zarobki”; „trudności w znalezieniu pracy”; „humanista ma najczęściej problem ze znalezieniem pracy, ponieważ jego szeroki zakres wiedzy powoduje, że nie może się on skupić na jednej dziedzinie”.

Ostatnie pytanie, skierowane do respondentów, brzmiało: „Czy potrzebni są dzisiaj humaniści? Krótko uzasadnij swoją opinię".

Już na wstępie analizy tej dyspozycji wypada podkreślić, że 98\% ankietowanych studentów Wydziału Humanistycznego UMCS dostrzega potrzebę istnienia humanistów. Swoje wypowiedzi wzmacniają oni przysłówkami: „bardzo”, „zdecydowanie”, np.: „Humaniści są bardzo potrzebni, szczególnie biorąc pod uwagę fakt, że Polacy coraz gorzej mówią własnym językiem, nie uczestniczą w kulturze (która wychodzi do ludzi) oraz nie czytają literatury. Warto dbać o Wydziały Humanistyczne należące do uniwersytetów i dobrze kształcić studentów, co z pewnością zaprocentuje w przyszłości i będzie korzystne dla Polski";

Zdecydowanie! Humanista, jak powszechnie się przyjęło, to osoba która potrafi prowadzić konwersację z różnymi ludźmi oraz szukać ścieżek (nowych ścieżek) rozwiązywania problemów. Tacy ludzie są niezwykle potrzebni, ponieważ przedstawiciele innych zawodów (mam tu na uwadze nauki ścisłe) zazwyczaj uczeni są typowych i utartych schematów przy rozwiązywaniu kwestii spornych. Nie potrafią wyjść poza schemat. Dodatkowo humanista to osoba, która zdecydowanie lepiej zna i włada językami (dane $\mathrm{z}$ badań). Świat się rozwija, wprowadzane są nowe technologie, powstają nowe firmy i instytucje, które prowadzą interesy na arenie międzynarodowej, toteż potrzebni są im wykwalifikowani pracownicy, znający język oraz potrafiący dostosowywać się do zmieniających się warunków pracy. 
Zaledwie 2\% respondentów albo nie dostrzega potrzeby humanistów we współczesnym świecie (Np.: „W dobie powszechnej cyfryzacji, skupiania się na nowych technologiach humaniści są mało potrzebnym reliktem przeszłości. Tak naprawdę dzisiaj nie są potrzebni”), albo sygnalizuje własne wątpliwości w tym zakresie między innymi poprzez zastosowanie partykuły modyfikującej „raczej” i przysłówka jakościowego „względnie” (np. „Humaniści są względnie potrzebni (np. takich historyków w Polsce jest przesyt lecz tłumaczy już nie). Zawsze przyda się tłumacz obcego języka. Archiwiści są również potrzebni. Ogólnie mówiąc wzięcie na rynku pracy mają osoby po kierunkach ścisłych, gdyż ich wiedza skupia się na konkretnej dziedzinie nauki, natomiast humanista musi mieć dość sporą wiedzę z kilku dziedzin nauk humanistycznych”; „powiedziałbym, że są raczej potrzebni, ale nie tak bardzo jak przedstawiciele nauk ścisłych)".

Studenci, którzy nie wyrażają żadnych obiekcji związanych z koniecznością istnienia humanistów, uzasadniają to:

a) zagrożeniami wynikającymi z ich braku: „Oczywiście, że są potrzebni. Bez nich społeczeństwo by zidiociało do reszty”; „Oczywiście, w dzisiejszych czasach jak najbardziej potrzebni są humaniści. Uważam tak, ponieważ moim zdaniem takie osoby wiele wprowadzają do życia innych, chociażby tym, że pokazują niektórym, w jaki sposób właściwie się wysłowić. Sądzę, że bez humanistów ludność cofałaby się w rozwoju”; "Gdyby nie humaniści kultura ległaby w gruzach”; „Tak ponieważ potrzebujemy przywódców, ludzi myślących, by tworzyć demokrację (nie ochlokrację, czyli „rząd motłochu”, niedoświadczonego, bezwolnego tłumu) i unikać technokracji, czyli ustawienia świata pod linijkę i statystykę, niemające wiele wspólnego z rzeczywistością (bo technokracji człowiek umyka, a humaniście nie)”; „Bez humanistów świat byłby „sztywny”, ograniczony do liczb, przepisów, reguł”;

b) korzyściami wynikającymi z ich istnienia, które dotyczą:

- terytorium Polski: „Dzisiaj potrzebni są humaniści, ponieważ utrzymują i pielęgnują mowę ojczystą, działają na rzecz społeczeństwa”; „Tak, ponieważ w dzisiejszych czasach, które zbombardowane się nowymi technologiami, potrzebne są osoby pielęgnujące tradycję, kulturę i język. Chroniące je przed wyparciem i zanikiem”; „Ktoś musi pilnować by absolwenci kierunków technicznych używali poprawnej polszczyzny”; „Przyczyniają się do wykształcenia nowego pokolenia Polaków w dziedzinie gramatyki, czytania, pisania";

- rozciagają się na cały świat: „Moim zdaniem humaniści są dzisiaj bardzo potrzebni. Humanista to szerokie spektrum możliwości. Wykształcenie humanistyczne daje możliwość szybszego, bardziej efektywnego rozpozna- 
nia oczekiwań i motywacji dla osoby, dla której się pracuje. Pozbawienie świata człowieka humanistyki, skaże nas na jakąś jednowymiarowość. Tak jak nie może istnieć świat bez wartości, tak nie może istnieć bez humanistów”; „W dobie ogólnoświatowej cyfryzacji coraz więcej ludzi odbiega od nauk humanistycznych, zapominając o doskonaleniu siebie, są zapatrzeni tylko i wyłącznie w Internet. Moim zdaniem humaniści są nadal potrzebni, aby nauki humanistyczne nie zanikły, a świat miał ludzkie oblicze”; ,Świat potrzebuje przecież rozgarniętych ludzi, którzy umieją poruszać się na każdej płaszczyźnie”; „Humaniści to ludzie szerokiej wiedzy. Dzisiaj znajomość języków jest bardzo potrzebna. Humanista rozwija się razem ze światem".

Wskazując potrzebę istnienia humanistów, respondenci nie precyzują, w jaki sposób mieliby oni przyczynić się do realizacji tych wszystkich zadań, które im wyznaczają, a więc: pielęgnowania języka, krzewienia kultury, dbałości o tradycję, godnego życia. Niekiedy wręcz emfatycznie, co ma również wyrażać wykrzyknik, stwierdzają: „Humaniści mają nieocenioną! wprost rolę w społeczeństwie”. Przymiotnik „nieoceniony” służy, prawdopodobnie, w ich odczuciu podkreśleniu zasług, które są tak wielkie, że brakuje skali. Wypowiedzi studentów przybierają również bardzo patetyczne tony wówczas, gdy humaniści prezentowani są w nich jako łącznicy między dawnymi i przyszłymi laty (np.: „Uważam, że humaniści są dzisiaj potrzebni. Zwłaszcza dziś, gdy technika przeżywa rozkwit. Myślę, że to humaniści dbają o rozwój duszy człowieka i przypominają o istnieniu moralności. Są łącznikiem między przeszłością i przyszłością, między różnymi spojrzeniami na świat”) czy niemal romantycy z utworu Adama Mickiewicza („Humaniści są wrażliwymi ludźmi. W dobie pośpiechu i kalkulacji mało kto zwraca uwagę na drugiego człowieka, niewiele osób pamięta i zgłębia sztukę bezinteresownie (czyli żeby udowodnić słuszność lub nie - swoich twierdzeń, zarzutów, np. w polityce). Humaniści patrzą i widzą, myślą i czują. Mają serce i dostrzegają serce innego człowieka").

Ankietowani, wartościując niezwykle pozytywnie humanistów, deprecjonują nie-humanistów, pisząc: „Tacy ludzie [humaniści] są potrzebni, ponieważ przedstawiciele innych zawodów (mam tu na uwadze nauki ścisłe) zazwyczaj uczeni są typowych i utartych schematów przy rozwiązywaniu kwestii spornych. Nie potrafią wyjść poza schemat; Ich wiedza [humanistów, a nie przedstawicieli innych dyscyplin] sprawia, że nie zadawalają się «suchymi informacjami», chcą wiedzieć, dlaczego coś się wydarzyło, jakie mogą być skutki”; „Ludzie pracujący umysłowo - humaniści również są bardzo potrzebni, aby uwrażliwiać społeczeństwo, uświadamiać mu różne rze- 
czy, aby człowiek nie pracował mechanicznie, aby był skłonny do refleksji, czego nie uczą inne kierunki”.

Tak więc konstatacje młodych ludzi można by wpisać w formułę: „Humaniści byli, są i będą". Kończąc nasze ustalenia, chcielibyśmy przywołać jedną z entuzjastycznych wręcz wypowiedzi, najtrafniej oddającą przekonania humanistów o samych sobie, które odpowiadają - naszym zdaniem - bardziej myśleniu życzeniowemu, nie zawsze mając pokrycie w rzeczywistości: „Humanista posiada szerokie horyzonty myślowe, jest wszechstronnie uzdolniony, wykształcony. Żadna nauka nie jest mu obca. Potrafi czytać ze zrozumieniem, poprawnie pisze po polsku. Posiada szerokie horyzonty, umiejętności społecznie przydatne $\mathrm{w}$ pracy $\mathrm{z}$ ludźmi. Humanista to człowiek wrażliwy społecznie i przystosowujący się do zmieniającego się świata”.

\section{THE IMAGE OF A PERSON WITH A HUMANITIES BACKGROUND AS VERBALIZED BY STUDENTS AT THE MARIA-CURIE SKŁODOWSKA UNIVERSITY IN LUBLIN}

\section{Summary}

Reflecting on the place of humanities in contemporary science and education, the authors attempt to reconstruct the self-stereotype of a humanities person, relying on a survey conducted among 250 students of the Faculty of Humanities, Maria Curie Skłodowska University. The survey offered an opportunity to analyze the perceptions of humanities and persons associated with this broad scientific field.

Their statements do not corroborate the convictions widespread in the public discourse, namely that persons with a background in humanities are superfluous. At the same time, they quote a broad range of professions which such people might practice thanks to versatile competences. However, they do note negative consequences of choosing a humanities-related path in life, such as financial ramifications and difficulties in finding employment. 


\section{Bibliografia}

Bańko M. (red.) 2000, Inny słownik języka polskiego, Warszawa.

Bartmiński J. 1988, Definicja kognitywna jako narzędzie opisu konotacji słowa, [w:] Konotacja, J. Bartmiński (red.), Lublin, s. 169-183.

Bartmiński J. 2007, Stereotypy mieszkają w języku. Studia etnolingwistyczne, Lublin.

Bartmiński J. i Panasiuk J. 2001, Stereotypy językowe, [w:] J. Bartmiński (red.), Współczesny język polski, Lublin, s. 371-395.

Bilewicz M., Antonowicz D. i Kulczycki E. 2014, Wielki świat lub zaścianek [online]. Forum Akademickie, [dostęp: 2016-05-15]. Dostępny w Internecie: <https://forumakademickie.pl/ fa/2014/03/kronika-wydarzen/wielki-swiat-lub-zascianek/>.

Błoch B. i Doliński D. 2004, Dwufazowy model powstawania stereotypów, [w:] M. Kofta (red.), Myślenie stereotypowe i uprzedzenia. Mechanizmy poznawcze i afektywne, Warszawa, s. 203-219.

Bokszański Z. 1997, Stereotypy a kultura, Warszawa.

Chałasiński J. 1935, Antagonizm polsko-niemiecki w osadzie fabrycznej „Kolonia” na Górnym Śląsku, Przegląd Socjologiczny III.

Cyceron M.T. 2010, O mówcy, Kęty.

Dębiński A. 2013, Humanistyka umiera. To fakt. [online]. Gazeta.pl [dostęp: 2016-05-15]. Dostępny w Internecie: <http://lublin.wyborcza.pl/lublin/1,48724,14993992,Rektor_KUL_ Humanistyka_umiera_To_fakt.html\#ixzz4815aRifk>.

Karwatowska M., Szpyra-Kozłowska J. 2010, Lingwistyka płci. Ona i on w języku polskim, Lublin.

Kofta M., Jasińska-Kania A. (red.) 2001, Stereotypy i uprzedzenia. Uwarunkowania psychologiczne i kulturowe, Warszawa.

Kokowski A. i Litwiński R. 2014, Czy humanistyka umiera?, Wiadomości Uniwersyteckie 4-5, s. 41-42.

Król M. 2014, Dlaczego musimy się zmienić? [online]. Wyborcza.pl [dostęp: 2016-05-15]. Dostępny w Internecie: <http://wyborcza.pl/magazyn/1,136824,15706650, Dlaczego_ musimy_sie_zmienic.html $>$.

Krzemińska A. 2015, Erudyta zawsze modny, Polityka 3, s. 62-64.

Krzyżanowski P. 1993, O rodzajach definicji i definiowaniu w lingwistyce, [w:] J. Bartmiński, R. Tokarski (red.), O definicji i definiowaniu, Lublin, s. 387-400.

Lippmann W. 1922, Public Opinion, New York.

Mikulski K. i Wijaczka J. 2014, Humanista - technoidiota czy świadomy empatyczny współobywatel, Nauka 3, s. 141-149.

Myśliwiec K. 2014, Dopiero za dwa pokolenia nam się poprawi [online]. Wyborcza.pl [dostęp: 2016-05-15]. Dostępny w Internecie: <http://wyborcza.pl/1,75400,15837837,Prof_Karol_ Mysliwiec_dopiero_za_dwa_pokolenia_nam.html\#ixzz48jZZbEtj>.

Nelson T.D. 2003, Psychologia uprzedzeń, Gdańsk.

Nowak P. 2002, swOI i OBCY w językowym obrazie świata. Język publicystyki polskiej z pierwszej połowy lat pięćdziesiątych, Lublin.

Pilch T. 1998, Zasady badań pedagogicznych, Warszawa.

Pszoniak J., „Obraz w głowie” - stereotyp jako sposób postrzegania grup obcych i swojej [online]. KYMU[dostęp: 2015-08-20]. Dostępny w <Internecie: kymu.edu.ua/wsc/toms/10/128-136. pdf $>$.

Szymczak M. (red.), Słownik języka polskiego, 1, Lublin.

Telus M. 1998, Stereotyp grupowy a predykacja, [w:] J. Anusiewicz, J. Bartmiński (red.), Język a Kultura, 12: Stereotyp jako przedmiot lingwistyki. Teoria, metodologia, analizy empiryczne, Wrocław, s. 135-145.

Zaczyński W. 1995, Praca badawcza nauczyciela, Warszawa. 